\title{
SEROPREVALENCE OF HEPATITIS B AND C VIRUSES: AWARENESS AND SAFE PRACTICES OF HAIRDRESSERS IN IZMIR - A SURVEY
}

\section{ŞUKRAN KOSE ${ }^{1}$, ALIYE MANDIRACIOGLU ${ }^{2}$, AHMET MURAT ORAL ${ }^{3}$, MESTAN EMEK $^{3}$, AYHAN GOZAYDIN ${ }^{1}$, LUTFIYE KUZUCU ${ }^{1}$, and MELDA TURKEN ${ }^{1}$}

${ }^{1}$ Tepecik Training and Research Hospital, Izmir, Turkey

Infectious Diseases and Clinic Microbiology Department

${ }^{2}$ Ege University, Izmir, Turkey

Department of Public Health of Medical Faculty

${ }^{3}$ Ministry of Health, Izmir, Turkey

\begin{abstract}
Objectives: The aim of the study is to determine the seroprevalence of hepatitis B (HBV) and hepatitis C virus (HCV) infection in barbers and to assess the awareness of these employees related to occupational risks of HBV and HCV. Materials and Methods: In this study, 2145 barbers in Izmir were given an occupational safety seminar. Blood samples were collected from 2066 voluntary participants and 1284 individuals completed the questionnaires. Sera were tested for the presence of HBV and HCV markers by ELISA. Results: Our results document low levels of knowledge about HBV and HCV infection, risk perception and adequate protection among participants before the seminar session. Of the participants, $63.5 \%$ reported that they had suffered from equipment-related injuries during the last month. The prevalence of $\mathrm{HBsAg}$ positive and anti-HCV individuals of the 2066 person was found to be $2.2 \%$ and $0.4 \%$, respectively. Conclusions: Hairdressers' knowledge of HBV, HCV and health hazards associated with their profession was inadequate. The prevalence of $\mathrm{HBs} \mathrm{Ag}$ positive and anti-HCV was similar to that among the general population.
\end{abstract}

Key words:

Knowledge, Attitudes, Blood-borne infections, Hairdresser, Barber, Seroprevalance

\section{INTRODUCTION}

People used to perform mutual hair-cutting up to the fifteenth century. Subsequently, the hairdressing business appeared. It is well known that in those times, barbers used to cut not only hair and beards but also performed circumcision, tooth extraction, blood letting with leeches, treated people for baldness, scabies and lice and acted as community physicians. The number of barbers opening up barber-shops started increasing gradually with the spread of hair-fashion and the increase in the use of cosmetics [1,2]. In time, it was recognized that this occupational group was critical in terms of the spread of some health problems among the population. Guidelines were established for the health and reliability of applications performed in barber shops, hairdressing and beauty centres and in places where tattooing and other applications were done [3]. Individuals working in barber shops, hairdressing and beauty centers are likely to have contact with blood

Received: March 12, 2011. Accepted: June 7, 2011.

Address reprint request to A. Mandiracioglu, Ege Universitesi, Tip Fakultesi, Halk Sagligi, Bornova 35100, Izmir, Turkey (e-mail: aliye.mandiracioglu@ege.edu.tr). 
though applications such as shaving, manicure, pedicure and skin care. It has been indicated in a number of studies that both customers and employees are under the risk of transmission of certain diseases if the necessary care is not practiced for individual hygiene, decontamination of working equipment, disinfection and sterilization, disposal of waste and the cleanliness of the work area [4-6]. In developing countries, it is highly important for barber and hairdressing salons not to use the same instruments successively for all customers without sterilization, especially in terms of diseases spread through the blood [7-9]. In our country it is reported that the carriage-frequency of $\mathrm{HBV}$ is between $4-5 \%$ [10]. HCV infection was $0.8 \%$ within the normal population in Turkey [11]. In a study performed in China, the HBV seropositivity was found to be higher in barbers than in the control group [12]. In a study by Mele et al. a relationship was found between shaving in barber shops and hepatitis [13]. In Italy, in hairdressing care processes the risk of hepatitis B for the population was found to be $1.7 \%$ and risk of hepatitis $\mathrm{C}$ was $1.8 \%$. It was estimated that $15 \%$ of acute hepatitis B cases and $11.5 \%$ of hepatitis $\mathrm{C}$ cases resulted from this type of exposure [14].

The aim of this study is to determine the seroprevalence of HBV, HCV among the study group and to assess the awareness of employees at barber shops, hairdressing and beauty centres concerning the occupational risks of blood-borne diseases and the effect of health education on knowledge of hepatitis B and C.

\section{MATERIALS AND METHODS}

\section{Study Population and Enrolment Procedures}

This survey was carried out in barber shops, hairdressing and beauty centers located in the Buca, Gaziemir, Narlıdere, Bornova and Konak municipal districts of Izmir in 2006. All employees from 300 workplaces were invited to participate in a seminar on blood borne diseases and occupational safety. A total of 2145 persons (employers and employees) were given a briefing. Their knowledge and practices were measured by pre- and post-testing during the seminar class and 1284 individuals completed selfadministered questionnaires.

During the seminar, the diseases transmitted through blood, the means of transmission and methods of protection were described. Participants were also instructed that hands should be thoroughly washed before and after each process and that gloves should be used if necessary. Instruction was also given on how to perform decontamination, attain a higher level of disinfection and sterilization processes for instruments used in the workplace, how to dispose of bodily wastes such as hair, beard, finger nails and how to handle sharp and puncturing instruments such as razors and epilating needles and the materials used in these processes.

In total, 1284 individuals completed the pre-and posttraining questionnaires. The effect of intervention on knowledge was evaluated from the answers. Questionnaires included questions on participants' gender, age, and occupational position, number of years in this occupation, their knowledge about diseases spread by blood, whether they took precautions against these diseases while working, and vaccination status.

An informed consent was received from each participant.

\section{Serological Assays}

All seminar participants were offered voluntary counselling and serological testing for HBV and HCV, 2066 persons had blood samples taken. Blood samples were collected into jelly vacuum tubes by the standard method from the brachial veins of individuals in aseptic conditions and stored at $-20^{\circ} \mathrm{C}$. These samples were analyzed in the Tepecik Hospital Infectious Diseases clinic laboratory. HBV and HCV infection markers included surface antigen (HBsAg ), surface antibody (anti-HBs), core antibody (anti-HBc) for HBV and HCV antibodies 
(anti-HCV). Blood was tested for these serological markers using a commercial enzyme-linked immunosorbent assay test ELISA. All serological markers for HCV and HBV were tested with only one type of detection kit ELISA (DiaSorin, Saluggia, Italy).

\section{Statistical Analysis}

The study data was evaluated by SPSS version 13.0 computer software package. Chi-square analysis was performed to test for differences in the proportions of categorical variables between two or more groups.

The study received ethical approval and permission from the Ministry of Health. Each potential participant was informed of the purpose of the study, and the fact that the study was completely voluntary and all data collected would remain confidential. Oral consent to participate in this study was obtained.

\section{RESULTS}

The mean age of individuals participating in the study was calculated as $29.44 \pm 10.28$ (ranging $12-77$ years). Of the participants, $59.9 \%$ were men; the educational level was elementary school in $40.8 \%$, middle school in $32.2 \%$, high school in $23.3 \%$ and university level in $3.7 \%$. Their mean length of time in work was $12.88 \pm 9.28$ years (ranging 1-55 years). Of the subjects, $58.4 \%$ reported that they were working in women's hairdressing salons, 31.5\% in beauty centres and $10.1 \%$ in barber shops. As much as $56.1 \%$ of the participants were employers. Of the

Table 1. Demographic characteristics of the participants according to HBV and HCV seroprevalence

\begin{tabular}{lccc}
\hline \multicolumn{1}{c}{ Characteristics } & $\begin{array}{c}\text { Total } \\
(\%)\end{array}$ & $\begin{array}{c}\text { HBsAg }(+) \\
(\%)\end{array}$ & $\begin{array}{c}\text { Anti-HCV }(+) \\
(\%)\end{array}$ \\
\hline Gender* & & & 0.4 \\
male & 50.9 & 1.8 & 0.5 \\
female & 49.1 & 0.3 & - \\
Age groups [in years]* & & & 0.2 \\
$15-17$ & 9.3 & - & 0.3 \\
$18-29$ & 46.6 & 0.5 & - \\
30-39 & 28.8 & 1.4 & - \\
40-49 & 10.2 & 3.1 & 0.2 \\
$>$ 50 & 5.1 & 3.2 & - \\
Education & & & - \\
elementary & 40.8 & 4.2 & - \\
middle school & 32.2 & 1.2 & 0.1 \\
high school & 23.3 & 1.4 & 0.1 \\
university & 3.7 & - & 0.3 \\
Type of beauty salon & & & \\
women's hairdressers & 58.4 & 0.6 & 1.2 \\
barbers & 10.1 & 1.9 & \\
beauty centres & 31.5 & & \\
\hline
\end{tabular}

$* \mathrm{p}<0.05$ for $\operatorname{HBsAg}(+)$. 
Table 2. The measures taken by employees against blood-borne diseases

\begin{tabular}{lc}
\hline \multicolumn{1}{c}{ Items } & Respondents \\
& $\mathrm{N}=1284(\%)$ \\
\hline The methods used in cleaning of instruments & 3.4 \\
use of customer owned epilating needle or manicure instruments & 80.9 \\
ultraviolet sterilizer instruments & 13.9 \\
boiling & 41.7 \\
wiping with cologne/alcohol & 9.2 \\
wiping with soap and water & 5.9 \\
sterilizing with a naked flame & 12.7 \\
washing with an antiseptic solution & 9.1 \\
use of a different razor for each customer & 4.4 \\
use of a drying oven & \\
Hand Washing frequency & 3.0 \\
when remembered & 21.2 \\
before each process & 22.4 \\
after each process & 75.6 \\
before and after each process & \\
Disposal of bodily waste and tools used & \\
those disposing with other trash & 75.6 \\
those disposing by collecting separately & 20.2 \\
those disposing by decontamination & 4.2 \\
those using disinfectants for the correct length of time & 56.8 \\
those diluting the disinfectants correctly & 75.8 \\
If an injury occurs to the customer during process & 35.9 \\
those using bloodstone for coagulation & 19.7 \\
those applying dry cotton & \\
those applying cologne with cotton & \\
\hline
\end{tabular}

workplaces, $15.1 \%$ for which training was provided were of 1 st class barber status, $53.3 \%$ were 2 nd and the remaining were $3 \mathrm{rd}$ or below. Of the employees, $23.7 \%$ were performing manicure/pedicure, $60.4 \%$ hairdressing, $7.2 \%$ beauty processes and $23.7 \%$ shaving (some employees performed more than one procedure).

Of the 2066 barbers and hairdressing employees, 2.2\% ( $\mathrm{n}=46$ ) were HBsAg positive anti-HBs negative anti$\mathrm{HBc}$ positive. Of the whole group, $0.4 \%(\mathrm{n}=9)$ were anti-HCV positive. Five anti-HCV positive persons were females. HBV seroprevalence was associated with gender $(p<0.05)$, the seroprevalence of HBsAg was higher in men (Table 1). It was determined that 1446 individuals $(70 \%)$ were HBsAg and anti-HBs negative; 538 individuals $(26.1 \%$ ) were $\mathrm{HBsAg}$ negative but anti-HBs positive; 36 individuals $(1.7 \%$ ) were $\mathrm{HBsAg}$, anti-HBs negative and anti-HBc positive.

Almost $81.0 \%$ of the employees reported that they had experienced accidents which were accidental cuts with razor blades, scissors and manual clippers during the last month. 
When the individuals were asked which contagious diseases constitute occupational risks for them, $77.0 \%$ replied hepatitis B, $44.1 \%$ AIDS, $42.3 \%$ alopecia, $30.7 \%$ allergic eczema, $15.5 \%$ flu and $8.7 \%$ pediculosis.

Eighty two of respondents reported refusing to serve customers with hepatitis-B. There was a significant difference between men and women. Male responders were more willing to serve customers with hepatitis-B. Only $75 \%$ of the respondents reported that they had ever heard of HBV carriers. Gender was associated with awareness of hepatitis B carriers - the female participants had a higher level of knowledge than the males ( $p<0.001)$.

Specifically, we found that nearly one-half of the survey respondents were not familiar with the virus liver damage. The rates of wrong answers were much higher for transmission routes before the training $(p<0.001)$. Before the training, the knowledge of the most important potential transmission routes of HBV (sexual transmission, blood transfusion, needle sharing) was higher than of other transmission routes. Of the participants, $17.8 \%$ knew about vertical HIV transmission. Regarding the transmission route of hepatitis $\mathrm{B}$, answers of $15.1 \%$ and $31.5 \%$ participants were wrong, such as hepatitis may be transmissible by coughing and by kissing, respectively. There was no statistical significance between educational level and the ratio of right answers.

It was determined that $32.1 \%$ of the participants had received hepatitis B-related information from the media, $7.6 \%$ from friends, $20.7 \%$ from health personnel and $12.8 \%$ had never heard of it at all. As much as $92.6 \%$ emphasized the necessity of being informed of diseases spread by blood.

On the other hand, 9.5\% had never previously heard of a hepatitis B vaccine. Approximately $9.5 \%$ of the subjects who replied to the questionnaires while participating in the training sessions stated that they had received hepatitis $\mathrm{B}$ vaccine before training. Of these, $4.5 \%$ gave a history of previous hepatitis-B infection.

The measures for cleaning, disinfection and sterilization of instruments and the practices related to the precautions

Table 3. Subjects' pre- and post-training hepatitis-B-related information levels

\begin{tabular}{lcc}
\hline \multicolumn{1}{c}{ Items } & $\begin{array}{c}\text { Pre-testing } \\
\mathrm{N}=1284 \\
(\%)\end{array}$ & $\begin{array}{c}\text { Post- testing } \\
\mathrm{N}=1114 \\
(\%)\end{array}$ \\
\hline Those stating that their occupation is risky in regard to hepatitis-B & 77.0 & 96.0 \\
Those stating that they would provide service to customers known to have hepatitis-B & 18.1 & 42.3 \\
Those who have heard of carrying of hepatitis-B & 75.0 & 86.4 \\
Those who were aware that hepatitis-B caused liver damage & 44.8 & 95.8 \\
Their answers to the hepatitis-B transmission ways* & & 3.4 \\
hugging, embracing, shaking hands, social kissing & 10.3 & 5.6 \\
cough, sneeze & 31.5 & 3.3 \\
jointly used razors, scissors and epilating needles, manicure-pedicure devices & 15.1 & 98.7 \\
blood infusion & 89.3 & 99.2 \\
insect bite & 93.5 & 4.7 \\
sexual intercourse & 14.7 & 99.7 \\
mother to infant transmission & 89.9 & 89.8 \\
needle tattooing & 17.8 & \\
\hline
\end{tabular}

\footnotetext{
* Multiple answers were allowed.
} 
taken by employees against blood-borne diseases are shown in Table 2. They reported a variety of methods of cleaning instruments: use of ultraviolet cleaner (80.9\%), washing and soaking (9.2\%), boiling (13.9\%), immersion in disinfectant $(12.7 \%)$. The use of dry heat sterilization was very low. Many of the respondents were not washing their hands before and after procedures. Most of the participants disposed of their used blades in municipal waste bins or open places. Their pre-and post-testing knowledge levels are shown in Table 3. The analysis of each response showed that they were less aware of their occupational risk for hepatitis at the beginning of the training. When assessing their own exposure to hepatitis infection associated with conducting their duties, female participants estimated it to be higher than men $(\mathrm{p}<0.001)$.

\section{DISCUSSION}

There are not many studies on HBV or HCV prevalence in barbers and hairdressers, even though they are a risk group. In our study, HBsAg positivity was detected in $2.2 \%$ of the study sample. Turkey is in the middle-endemic region of 2-10\% for hepatitis B. In our country, HCV infection is lower than that of HBV [15]. In a study carried out in Sivas, Turkey, the HCV prevalence in 176 barbers and hairdressers was found to be 2.8\%; and HBsAg positivity was $8.5 \%$ [16]. A study carried out by Özdemir et al. in Sivas reported that HBsAg seropositivity was detected in $1.1 \%$ of barbers, hairdressers, and employees of beauty salons; anti-HBs $-22.8 \%$; anti-HCV $-0.4 \%$ [17]. A difference between the rates of prevalence observed in these studies and others carried out in Turkey is observed. The prevalence of HBV and HCV infections varies from country to country, and even from one region to another, based on environmental factors and host characteristics [16]. The area where our study took place was Izmir, a city in the west of Turkey and the 3rd biggest city in the country. It has high socioeconomic and educational levels as well as better climatic conditions. The city where the other study took place, Sivas, is a much smaller city in the east with a lower socioeconomic and educational level.

In the Izmir study, there was a significant association between HBsAg positive seroprevalence and gender. In the other Turkish study conducted in Sivas, there was no significant difference in $\mathrm{HBsAg}$ positive seroprevalence between the two genders [17].

This survey showed that the seminar program resulted in a positive change in the knowledge of barbers, hairdressers and beauticians regarding hepatitis-B. There was a significant difference between the knowledge of this group pre- and post-testing.

The analysis of each response showed that participants were less aware of their occupational risk for hepatitis at the beginning of the seminar. Only $75 \%$ of the respondents reported they had ever heard of HBV carriers. Specifically, we found that nearly one-half of the survey respondents were not familiar with virus liver damage. The rate of wrong answers was much higher for transmission routes before the seminar. In previous studies, the information levels of employees regarding to hepatitis-B were found to be insufficient $[4,5,18,19]$.

It is reported that the hepatitis-B virus can survive many days on a drop of dried blood, on needles, on surfaces, on injectors and on razors [17]. Therefore, in cases where preventive measures against infection are ineffective, the risk of infection transmission to employees injured by these instruments is very high. In this study, $63.5 \%$ of the employees reported that they had been injured within the last 30 days. In an Australian study by Murtagh and Hepworth, it was discovered that $80 \%$ of the employees had had contact with blood within the week prior to the study. It is necessary to have high standards for sterilization of sharp cutting instruments such as razors, scissors used in a hairdressing salon [20].

The present study is important since it has accessed many more individuals than previous studies designed to assess 
the information levels of barber and hairdressing employees in relation to hepatitis-B. There are several limitations. It is unclear to what extent our findings would be generalizable to the whole of Turkey. The results depend on self-reporting, as we could not perform objective observations to assess instrument use and sterilization practices. Infection with $\mathrm{HBV}$ and $\mathrm{HCV}$ is an important occupational hazard of barbers, especially in developing countries [7-9,16]. In Turkey, many barbers and hairdressers also perform manicure, pedicure and epilating. It was apparent that the sterilization methods applied to the instruments used during this study were neither appropriate nor reliable; the employees failed to wash their hands frequently and also failed to pay the required attention to the use of gloves. Similar results were found in previous studies [3-5,18,21]. In addition, they disposed of their sharp instruments in municipal waste. Moghadam reported that the common practice of throwing razors openly in municipal waste baskets poses a major risk to sweepers and garbage handlers [18].

The struggle against hepatitis $\mathrm{B}$ and $\mathrm{C}$ disease should include all transmission routes. Not only those institutions that provide health care, but also barbers' and hairdressing salons where transmission is likely to occur, should comply with the necessary hygienic conditions and international regulations regarding infection control. Most of the studies have emphasized that, since HBV and HCV can be transferred by some professions, including hairdressers, it is very important to educate these professionals in order to prevent hepatitis B and $\mathrm{C}$ in their clients $[10,18]$. HBV vaccination of infants and adults with high-risk behaviour and some occupations (health care personnel, barbers) is a routine procedure in Turkey, as in most countries. But occupational transmission of $\mathrm{HCV}$ is of particular concern because of the absence of a prophylactic vaccine for $\mathrm{HCV}$ infection and the relatively high seroconvertability of the hepatitis $\mathrm{C}$ virus with the characteristics of the virus that allow it to live outside the body for some time $[5,22]$. In addition, there has been a considerable debate about $\mathrm{HCV}$, on whether infected individuals would benefit from early treatment and on whether asymptomatic people at high risk for hepatitis $\mathrm{C}$ should be screened or not [23]. So, awareness raising and continuing education is vitally important for workers. Public education is needed to empower clients to ask about safety [5]. Prevention is the only safeguard against the epidemic of viral hepatitis. The best way to prevent hepatitis B and C is to avoid the practices that increase the risk of infection. Knowing the facts and having the proper attitudes and behaviour are also critical to prevent the spread of these infections [24].

Behaviour changes regarding unhealthy practices and improving knowledge are important for this group. The barber and hairdressing salons should comply with the necessary hygienic conditions and international infection control regulations. The Turkish Republic Department of Health, with the publication of regulations no. 6856 dated 04 June 1998, evaluated for the first time barbers, hairdressers and manicurists/pedicurists under risk. Thus, this group of employees should be trained and monitored for diseases spread by blood with the efforts of the trade associations. Vocational courses and apprentice training centres should provide teaching of individual and occupational hygiene.

\section{REFERENCES}

1. Wazir MS, Mehmood S, Ahmed A, Jadoon HR. Awareness among barbers about health hazards associated with their profession. J Ayub Med Coll Abbottabad 2008;20(2):35-8.

2. Moore JE, Miller BC. Skin, hair and other infections associated with visits to barber's shops and hairdressing salons. Am J Infect Control 2007;35:203-4.

3. Oberdorfer A, Wiggers JH, Considine RJ, Bowman J, Cockburn J. Skin penetration operators' knowledge and attitudes towards infection control. Am J Health Behav 2003;27(2):125-34. 
4. Ruddy M, Cummins M, Drabu Y. Hospital hairdresser as a potential source of cross-infection with MRSA. J Hosp Infect 2001;49:225-7.

5. Murtagh MJ, Hepworth J. Hepatitis C in the workplace; a survey of occupational health and safety knowledge and practice in the beauty industry. Aust N Z J Public Health 2004;28:207-11.

6. Tumminelli F, Marcelin P, Rizzo S, Barbera S, Corvino G, Furia S, et al. Shaving as potential source of hepatitis $C$ virus infection [letter]. Lancet 1995;345(8950):658.

7. Abdul Khaliq A, Smego RA. Barber shaving and bloodborne disease transmission in developing countries. S Afr Med J 2005;95:94-5.

8. Baakrim MZ, Laraqui S, Laraqui O, El Kabouss Y, Verger C, Caubet A, et al. Infectious risks associated with blood exposure for traditional barbers and their customers in Morocco. Sante 2002;14(4):211-6.

9. Goudey RE, Thompson SC. Evaluation of infection control in registered tattooing premises in Victoria, 1994. Aust N Z J Public Health 1997;21:22-8.

10. Çakaloğlu Y, Oktem A, Yalçın S. Hepatitis-B virus infection seroepidemiology in Turkey. Turk Gastroenterohepatol 1990;1:49-53.

11. Balik I, Onil M, Kandilci S, Tekeli E, Tuncbilek S. The prevalence of HCV among different groups. Turk J Gastroenterol 1990;1:55-58.

12. She SL, Shi LY, Wu YJ, Li ZZ, Zheng CZ, Wu YP, et al. Seroepidemic study of hepatitis B virus infection among barbers in Huangshi City Hubei China. Microbiol Immunol 1998;32:229-33.

13. Mele A, Corona R, Tosti ME, Palumbo F, Moiraghi A, Novaco F, et al. Beauty Treatments and Risk of Parenterally Transmitted Hepatitis; Results from The Hepatitis Surveillance System in Italy. Scand J Infect Dis 1995;27:441-4.

14. Maiano A, Mele A, Tosti ME, Parlato A, Gallo G, Ragni P, et al. Role of beauty treatment in the spread of parenterally transmitted hepatitis viruses in Italy. J Med Virol 2004;72: 216-20.

15. Gurol E, Saban C, Oral O, Artuk C, Aksoy A. Trends in hepatitis $B$ and hepatitis $C$ virus among blood donors over 16 years in Turkey. Eur J Epidemiol 2006;21:299-305.

16. Candan F, Alagozlu H, Poyraz O, Sumer H. Prevalence of hepatitis $B$ and $C$ virus infection in barbers in the Sivas region of Turkey. Occup Med (Lond) 2002;52:311-4.

17. Ozdemir L, Alim A, Arslan S, Nur N, Kaya S, Demirel Y, et al. The Seroprevalance of HBV, HBC and HIV among Barbers and Hairdressers in the City Center of Sivas. J Fac Med Cumhuriyet Univ 2004;26:153-6 [in Turkish].

18. Moghadam MH, Mazloomy SS, Ehrampoush MH. The effect of health education in promoting health of hairdressers about hepatitis B based on health belief model: a field trial In Yazd, Iran. Acta Med Iran 2005;43:342-6.

19. Kisioglu AN, Ozturk M, Demirel R, Uskun E, Kirbiyik S. Evaluating the knowledge, attitudes and behaviors of male barbers related to hepatitis- $B$, located with the centrum Isparta. J Süleyman Demirel Univ Med Fac 2000;7:53-7 [in Turkish].

20. Lee WM. Hepatitis B Virus Infection. N Engl J Med 1997;337:1733-45.

21. Nayagam M. Hairdressing a health hazard [letter]. Aust Fam Physician 1995;24(1):88.

22. Williams S, Libotte V, Ramsay M. Compliance with follow-up after occupational exposure to hepatitis C. Occup Med 2007;57:596-8.

23. Sypsa V, Hadjipaschali E, Hatzakis A. Prevalence, risk factors and evaluation of a screening strategy for chronic hepatitis $C$ and $B$ virus infections in healthy company employees. Eur J Epidemiol 2001;17:721-8.

24. Khuwaja AK, Qureshi R, Fatmi Z. Knowledge about hepatitis $B$ and $C$ among patients attending family medicine clinics in Karachi. East Mediterr Health J 2002;8:787-93.

This work is available in Open Access model and licensed under a Creative Commons Attribution-NonCommercial 3.0 Poland License - http://creativecommons.org/ licenses/by-nc/3.0/pl/deed.en. 